\title{
Strukturalisme Genetik dalam Novel Alita @ Heart Karya Dewie Sekar
}

\author{
Fitria Andriani \\ (corresponding author) \\ Program Studi Magister Pendidikan Bahasa Indonesia, Universitas Bengkulu \\ Email: fitriaandriani342@gmail.com \\ Didi Yulistio \\ Program Studi Magister Pendidikan Bahasa Indonesia, Universitas Bengkulu \\ Email: didiyulistio@unib.ac.id \\ Agus Trianto \\ Program Studi Magister Pendidikan Bahasa Indonesia, Universitas Bengkulu \\ Email: agustrianto@unib.ac.id
}

APA Citation: Andriani, F., Yulistio, D., \& Trianto, A. (2021). Strukturalisme Genetik dalam Novel Alita @ Heart Karya Dewie Sekar. Silampari Bisa: Jurnal Penelitian Pendidikan Bahasa Indonesia, Daerah, dan Asing, 4(1), 173-180. https://doi.org/10.31540/silamparibisa.v4i1.1294

\begin{abstract}
Abstrak
Tujuan dari penelitian ini adalah untuk mendeskripsikan aspek struktural dan sosial budaya dalam novel Alita@ @eart karya Dewie Sekar melalui analisis strukturalisme genetik. Pendekatan yang digunakan adalah pendekatan sosiologi dengan menggunakan analisis strukturalisme genetik. Objek penelitian ini adalah novel Alita @ Heart karya Andrea Hirata. Data diperoleh dengan teknik membaca dan mencatat. Instrumen penelitian yaitu peneliti dibantu dengan tabulasi data yang menjelaskan batasan masalah. Data dianalisis dengan langkah-langkah: 1) membaca dan memahami novel, 2) mengidentifikasi data, 3) mengkaji unsur struktural yang terdapat dalam novel, 4) mengkaji kondisi sosial dan budaya masyarakat yang hidup pada masa karya sastra tersebut diciptakan, 5) mengkaji latar kehidupan sosial dan budaya pengarang yang mempengaruhi pandangan dunianya terhadap penciptaan novel, dan 6) menarik kesimpulan dari data yang diperoleh. Dari hasil analsis ini dapat diketahui bahwa pada aspek struktural yaitu alur yang terdiri dari alur buka, alur tengah, alur puncak, dan alur tutup. Dalam novel ini terdapat empat tokoh utama yaitu Alita, Yusa, Abel, dan Gading. Sedangkan tokoh tambahan meliputi Mama, Papa, Delita, Dayana, Lee, Juno, Ava, Rama, dan Aldo. Latar tempat yang digunakan meliputi kantor, kios, resto, rumah, Bali, Surabaya, dan Jakarta. Kemudian, latar waktu yang digunakan adalah masa lalu dan sehari-hari. Pada aspek kondisi sosial dan budaya masyarakat Jakarta yang diangkat dalam novel ini adalah kondisi masyarakat yang terjebak dalam kehidupan yang penuh dengan kesibukan aktivitas kerja, kemacetan, dan percintaan.
\end{abstract}

Kata kunci: strukturalisme genetik, novel 
Fitria Andriani, Didi Yulistio, Agus Trianto

Strukturalisme Genetik dalam Novel Alita @ Heart Karya Dewie Sekar

\title{
Genetic Structuralism in the Novel Alita @ Heart by Dewie Sekar
}

\begin{abstract}
The purpose of this study was to describe the structural and socio-cultural aspects of the novel Alita @ Heart by Dewie Sekar through the analysis of genetic structuralism. The approach used is a sociological approach using genetic structuralism analysis. The object of this research is the novel Alita @ Heart by Andrea Hirata. Data obtained by reading and note-taking techniques. The research instrument is the researcher assisted by data tabulation which explains the problem boundaries. The data were analyzed by the following steps: 1) reading and understanding the novel, 2) identifying the data, 3) examining the structural elements contained in the novel, 4) examining the social and cultural conditions of the people who lived at the time the literary work was created, 5) examining the background the author's social and cultural life that influences his world view on the creation of the novel, and 6) draw conclusions from the data obtained. From the results of this analysis, it can be seen that in the structural aspect, the grooves consist of open grooves, middle grooves, peak grooves, and closed grooves. In this novel there are four main characters, namely Alita, Yusa, Abel, and Gading. While additional characters include Mama, Papa, Delita, Dayana, Lee, Juno, Ava, Rama, and Aldo. The settings used include offices, kiosks, restaurants, homes, Bali, Surabaya, and Jakarta. Then, the time setting used is the past and everyday. In the aspect of social and cultural conditions of the people of Jakarta that is raised in this novel is the condition of the people who are trapped in a life full of busy work activities, traffic jams, and love.
\end{abstract}

Keywords: genetic structuralism, novel

\section{A. Pendahuluan}

Sastra memiliki unsur-unsur yang berupa pikiran, ide, perasaan, semangat, kepercayaan (keyakinan), ekspresi atau ungkapan, bentuk, dan bahasa. Hal ini dikuatkan oleh pendapat Saryono (2009:18) bahwa sastra juga mempunyai kemampuan untuk merekam semua pengalaman yang empiris-natural maupun pengalaman yang nonempiris-supranatural. Dengan kata lain sastra mampu menjadi saksi dan pengomentar kehidupan manusia. Seorang penulis sastra adalah anggota masyarakat yang mempunyai ide, gagasan, pendapat, dan pandangan tentang kehidupan pada setiap zamannya (Noermanzah, 2017:28). Novel merupakan salah satu bentuk prosa fiksi dengan masalah yang kompleks yang mampu memberikan manfaat yang besar bagi perkembangan kemanusiaan dan kehidupan manusia (Nurgiyantoro, 2010; Sulaeman dkk., 2020). Hal ini sesuai dengan pernyataan yang sering kita dengar bahwa novel mencapai keutuhannya secara inklus (inclusion), yakni bahwa novelis mengukuhkan keseluruhannya dengan kendali tema karyanya (Sayuti, 2000:26).

Para novelis menampilkan pengajarannya melalui berbagai tema dan amanat dalam novelnya, tema kemanusiaan, sosial, cinta kasih, ketuhanan, dan sebagainya. Untuk mengungkap unsur pembangun sastra bisa menggunakan pendekatan strukturalisme. Pendekatan strukturalisme berusaha meneliti teks sastra dari segi struktur, dengan melihat komponen-komponen yang membangun dan hubungan antar komponen tersebut (Ratna, 2008; Basid \& Aulia, 2018). Setelah mendapatkan kesatuan dan keutuhan teks, lalu dicari hubungannya dengan aspek sosio-budaya yang melatarbelakanginya. Dari hubungan inilah diharapkan makna teks sastra dapat dikonkritkan. Strukturalisme genetik mendiskripsikan pendekatannya dengan dua

Silampari Bisa: Jurnal Penelitian Pendidikan Bahasa Indonesia, Daerah, dan Asing

Vol. 4, No. 1, 2021 
prinsip pokok, yaitu strukturalisme dan genetik (Yuhdi, 2018; Sugianto \& Huda, 2017). Semi (1993:35) menyatakan bahwa berbicara mengenai anatomi fiksi berarti berbicara tentang struktur fiksi atau unsur-unsur yang membangun fiksi itu. Struktur fiksi itu secara garis besar dibagi atas dua bagian, yaitu: (1) struktur dalam (instrinsik) dan (2) struktur luar (ekstrinsik). Struktur dalam (instrinsik) adalah unsur-unsur yang membentuk karya sastra tersebut seperti tema, alur (plot), penokohan atau perwatakan, pusat pengisahan, latar, sudut pandang pengarang, dan gaya bahasa. Struktur luar (ekstrinsik) adalah segala macam unsur yang berada di luar suatu karya sastra yang ikut mempengaruhi kehadiran karya sastra tersebut, misalnya faktor sosial ekonomi, faktor kebudayaan, faktor sosio-politik, keagamaan, dan tata nilai yang dianut masyarakat (Anggraini, 2019).

Rumusan masalah dalam penelitian ini adalah 1) Bagaimana wujud unsur struktural karya sastra dalam novel Alita @ Heart karya Dewie Sekar?; 2) Bagaimana kondisi sosiaL dan budaya masyarakat yang hidup pada masa diciptakannya novel Alita@ Heart Karya Dewie Sekar?; dan Bagaimana latar kehidupan sosial dan budaya pengarang yang memperngaruhi pandangan dunianya dalam menciptakan novel Alita @ Heart karya Dewie Sekar? Kemudian, tujuan penelitian mendeskripsikan unsur struktural karya sastra yang terdapat dalam novel Alita @ Heart karya Dewie Sekar, mendeskripsikan kondisi sosial dan budaya masyarakat yang hidup pada masa diciptakannya novel Alita @ Heart karya Dewie Sekar, mendeskripsikan latar kehidupan sosial dan budaya pengarang yang memperngaruhi pandangan dunianya dalam menciptakan novel Alita @ Heart karya Dewie Sekar.

Penelitian ini dilakukan karena kajian terhadap novel Alita @ Heart karya Dewie Sekar belum ada yang meneliti. Akan tetapi, kajian strukturalisme genetik sudah banyak dilakukan dalam mengungkap isi novel, misalnya penelitian oleh Lestari (2020) tentang sosok perempuan Jawa dalam novel GGA prespektif Amangkurat I yang ditinjau menggunakan strukturalisme genetik, penelitian oleh Wicaksono (2017) tentang kearifan pada lingkungan hidup dalam beberapa novel karya Andrea Hirata dengan tinjauan strukturalisme genetik, dan penelitian oleh Syarifuddin (2020) tentang perwatakan tokoh pergerakan feminisme dalam novel Ahlâm Al-Nisâ Al-Harem karya Fatima Mernissi dengan menggunakan pendekatan strukturalisme genetik. Untuk itu kajian strukturalisme genetik dalam novel Alita @ Heart karya Dewie Sekar penting dilakukan karena bisa memberikan pemahaman tentang makna kondisi sosial dan budaya masyarakat yang diangkat dalam novel melalui unsur intrinsik dan ekstrinsik yang dibangun. Selain itu, dari hasil penelitian ini diharapakan novel Alita @ Heart karya Dewie Sekar bisa menjadi salah satu materi ajar pada materi menulis novel di tingkat SMA dan perguruan tinggi.

\section{B. Metode Penelitian}

Metode penelitian yang digunakan yaitu metode deskriptif kualitatif dengan pendekatan sosiologi dengan menggunakan analisis strukturalisme genetik. Pendekatan sosiologi dalam sastra adalah sebuah pendekatan yang mempertimbangkan segi-segi kemasyarakatan. Penelitian ini menggunakan analisis strukturalisme genetik dengan tujuan mengetahui kajian struktural karya sastra, kondisi sosial budaya masyarakat, dan konteks sosial pengarang.

Teknik pengumpulan data menggunakan teknik dokumentasi yang bersumber dari novel Alita@ Heart karya Dewie Sekar. Instrumen utama dalam penelitian ini 
adalah peneliti dibantu dengan tabulasi data yang mampu menginterpretasi data sesuai dengan rumusan dan tujuan penelitian.

Data dikumpulkan dari isi cerita novel Alita @ Heart karya Dewie Sekar yang bersumber dari novel Alita @ Heart karya Dewie Sekar. Data dianalisis berdasarkan membaca dan memahami novel Alita @ Heart karya Dewie Sekar kemudian mengidentifikasi data novel Alita@ Heart karya Dewie Sekar, mengkaji unsur struktural yang terdapat dalam novel Alita @ Heart karya Dewie Sekar, mengkaji kondisi sosial dan budaya masyarakat yang hidup pada masa karya sastra tersebut diciptakan, mengkaji latar kehidupan sosial, dan budaya pengarang yang mempengaruhi pandangan dunianya dalam menciptakan karya sastra, dan menarik kesimpulan dari data yang diperoleh mengenai novel Alita @ Heart karya Dewie Sekar. Untuk uji keabsahan data menggunakan member check dan validasi pakar sastra terkait interpretasi data penelitian.

\section{Hasil Penelitian dan Pembahasan 1. Hasil Penelitian}

Penelitian novel Alita @ Heart karya Dewie Sekar mengisahkan percintaan yang terjadi di kota metropolitan Jakarta. Berawal dari kematian mas Erwin yang merupakan pacar dari Alita yang membuat ia mengalami patah hati dan menutup diri untuk lelaki. Walau sudah dua tahun yang lalu bayangan Erwin masih terbayang dalam Alita. Hal ini lah yang membuat ia memilih untuk tetap sendiri tanpa cinta yang lain. Alita dan Erwin menjalin hubungan secara diam-diam dan tidak diketahui oleh keluarganya terutama pada kakak Alita yaitu Yusa yang merupakan sahabat dari Erwin. Hubungan mereka diketahui oleh Yusa setelah mereka menjalin hubungan selama satu tahun lebih, Yusa tidak menyetujui hubungan mereka karena Erwin merupakan lelaki yang memiliki banyak wanita kencan.

Begitu juga dengan Yusa yang mengalami kisah sama dengan adiknya. Ava yang merupakan cinta suci Yusa meninggal lebih dulu dari Erwin. Setelah meninggalnya Ava Yusa juga sempat menutup diri untuk wanita hal ini membuat yang sudah berumur juga belum menikah. Orang tua dari Alita dan Yusan selalu mendesak mereka untuk menikah dengan alasan umur mereka sudah tidak remaja lagi. Atas desakan orang tuanya Yusa mencoba untuk menjalin percintaan lagi dengan Dayana mitra bisnisnya, setelah diyakini sesuai Yusa melamar Dayana untuk menjadi istrinya. Namun, lamaran Yusan ditolak dengan alasan Dayana lebih mencintai langit dari padanya. Abel merupakan sahabat dari Alita yang memiliki bisnis kios bunga, usaha ini ia rintis sendiri, dan tanpa bantuan orang lain. Abel berhasil membuat bisnisnya berkembang pesat dan menjadikan ia sebagai seorang pengusaha sukses. Walau begitu Abel mengalami kegagalan dalam hubungan cinta.

\section{Pembahasan}

Berdasarkan isinya, struktruralisme genetik yang ditemukan di novel Alita@ Heart karya Dewie Sekar berupa unsur struktural karya sastra dalam novel Alita @ Heart, kondisi sosial dan budaya masyarakat pada masa penciptaan karya sastra, dan latar kehidupan sosial dan budaya pengarang yang mempengaruhi pandangan dunia dalam menciptakan novel Alita @ Heart karya Dewie Sekar. Hal ini sejalan dengan hasil penelitian Sundari (2015) yang mengemukakan bahwa struktur novel, lingkungan sosial budaya pengarang, dan latar belakang sejarah atau peristiwa sosial 
Fitria Andriani, Didi Yulistio, Agus Trianto

Strukturalisme Genetik dalam Novel Alita @ Heart Karya Dewie Sekar

masyarakat Indonesia yang mengkondisikan lahirnya novel Perahu Kertas. Pada penelitian ini diperoleh bahwa unsur struktural karya sastra dalam novel Alita @ Heart karya Dewie Sekar, kondisi sosial dan budaya pengarang dan kehidupan sosial, serta budaya pengarang yang mempengaruhi pandangan dunia.

\title{
a. Analisis Alur
}

Secara struktural alur memiliki kaitan yang sangat erat pada tokoh atau pelakunya dalam penceritaan yang melakukan perbuatan berbentuk rangkaian dialog dan memberikan gambaran perwatakan sehingga membentuk peristiwa yang saling berkaitan satu dengan yang lainnya.

Kalimat yang berupa alur salah satunya terdapat pada teks di bawah ini.

"Dua tahun sudah berlalu sejak Tuhan memutuskan menyingkirkan mas Erwin dari hidupku. Dua tahun lebih beberapa bulan. Hidup berjalan terus disekitarku tanpa aku benar-benar merasakan terlibat didalamnya. Sementara semua orang sepertinya adalah penghuni sah kehidupan, aku merasa diriku Cuma tamu yang diterima begitu saja oleh semesta....betangan luas langit menerima kehadiran bergumpul-gumpul awan."

(Sekar, halaman 5)

Kutipan novel di atas, pengarang menggambarkan bahwa Alita masih memendam kesedihan yang mendalam atas kematian pacarnya. Erwin meninggal dunia karena terserang penyakit HIV AIDS, yang mana pada saat Erwin sekarat tidak ada yang diperbolehkan menemuinya. Hal ini membuat Alita semakin bersedih, ia yang berkeinginan merawat Erwin di detik-detik terakhir hidupnya malah dilarang untuk berjumpa. Setelah kematian Erwin ia hanya bisa mendatangi tempat peristirahatannya yang terakhir. berikut.

Tahap alur buka pada novel Alita @ Heart karya Dewie Sekar pada kutipan

\begin{abstract}
"Mas Yusa jatuh hati pada Dayana, salah satu rekan bisnisnya, gadis cantik pedagang tanaman yang seusiannya kira-kira sebaya denganku. Hubungan tak berjalan mulus dan gadis itu kini bahkan sudah menikah dan sedang terkapar di rumah sakit gara-gara ngidam. Walau akhir hubungan mereka tak seperti harapanku, toh kuanggap ini awal bagus. Semacam bukti bahwa mas Yusa setidaknya masih bisa membuka hati setelah mbak Ava pergi jauh sekali." (Sekar, halalam 6)
\end{abstract}

Kalimat di atas dapat digambarkan pengarang pada penceritaan tokoh lain yaitu Yusa dan Abel. Yusa yang mengalami sakit hati atas kematian pacarnya Ava. Namun, hubungan percintaan mereka harus kandas karena Dayana lebih memilih menikah dengan Langit.

b. Kondisi Sosial dan Budaya Masyarakat pada Masa Penciptaan Karya Sastra

Kutipan yang tertera pada kondisi sosial dan budaya masyarakat pada masa penciptaan karya sastra, seperti pada kalimat berikut.

"Waktu aku belum pindah ke Jakarta dan masih tinggal di Surabaya beberapa tahun lalu, seorang gadis bernama Citra- Abel biasa memanggilnya cit-cit menyewa kamar yang kini kutempati ini dari Abel." (Sekar, halaman 47)

Pada kutipan di atas sebenarnya Alita dan Yusa bukanlah penduduk asli kota Jakarta, mereka pendatang dari Surabaya yang sama seperti pendatang lain

Silampari Bisa: Jurnal Penelitian Pendidikan Bahasa Indonesia, Daerah, dan Asing

Vol. 4, No. 1, 2021 
mencoba mengadu nasib mencari perkerjaan di ibu kota. Yusa yang pada saat itu sedang merasa putus cinta dan sakit hati ingin mencoba menjauh dari bayangan kekasihnya yang telah meningal. Hal ini banyak terjadi oleh para pendatang lain, yang datang ke Kota Jakarta karena ingin menjauhkan diri dari permasalahan pribadi seperti putus cinta, kecewa pada orang tua, lari dari utang, dan lain sebagainya.

Kalimat kedua yang tertera pada kondisi sosial dan budaya masyarakat pada masa penciptaan karya sastra, seperti pada kalimat berikut.

"Kurasa kamu jadi gitu justru karena kekurangan waktu. Kamukan kerja melulu. Pagi-pagi udah ngantor sampai jam tiga, habis itu kamu ngelesin sampai sampai jam sembilan malam. Sabtu juga masih ngelesin sampai siang. Libur cuma Mingu doang, itu pun kamu pakai buat tidur, atau ngumpet di gedung bioskop yang gelap, atau malah baca-baca doang seharian..." (Sekar, Halaman 15).

\footnotetext{
“Oh, jangan kawatir Ma. Aku 27 tapi gak hamil kok,"sahutku, lalu cengengesan. Barusan melucu walau rasanya cengeng banget.

Mama tertawa. "Mama malah pengin lihat kamu hamil kok lit..." desanya kemudian. "kamu sudah ada pikiran ke sana apa belum nih?" (Sekar, Halaman 57)

"Kadang-kadang aku senang karena belum pernah menikah.

Hanya kadang-kadang.

Lebih seringnya aku risau, sebab umurku sudah beberapa tahun melewati usia tiga puluh dan aku masih saja sendiri.. sementara banyak teman-temanku sudah mengeluh dengan bangga bahwa mereka baru memasukkan anak-anak mereka ke Play Group, TK, atau SD yang uang pangkalnya minta ampun mahalnya."

(Sekar, Halaman 99)
}

Pada kutipan di atas menggambarkan bahwa rutinitas yang dilakukan keseharian pada penduduk Kota Jakarta yang padat dan penuh dengan kesibukan dapat melupakan dirinya tentang persoalan menikah. Hal ini karena mereka setiap harinya selalu memikirkan kesibukan urusan pekerjaan yang membuat mereka lalai akan hal itu. inilah penyebab kenapa para remaja Kota Jakarta sering menikah setelah berada di usia tidak muda lagi.

\section{c.Latar Kehidupan Sosial dan Budaya Pengarang yang Mempengaruhi Pandangan \\ Dunia dalam Menciptakan Novel Alita @ Heart}

Teori struktural genetik meyakini bahwa karya sastra memiliki hubungan struktural atau homolog dengan struktural yang terdapat di dalam masyarakat (Andarini, 2018). Homolog merupakan kesejajaran struktural antara struktural karya sastra dengan struktural masyarakat tidaklah bersifat langsung. Melainkan hubungan padangan dunia yang tumbuh dan berkembang dalam masyarakat tersebut. Kondisi masyarakat membentuk kelas-kelas yang ada dalam posisi tertentu yang pada akhirnya membuahkan dan mengembangkan suatu pandangan dunia.

Sebagai pengarang novel Alita @ Hear yang menjadi kajian dalam penelitian ini, Dewie Sekar tentu memiliki pandangan dunia yang mendasarinya dalam menciptakan sebuah karya sastra. Padangan dunia itu tidak muncul secara tiba-tiba, melainkan terbentuk akibat pengaruh dari latar sosial dan budaya dalam hubungan dan interaksi dengan lingkungan masyarakat di sekitarnya. Dewie Sekar yang juga telah melahirkan beberapa karya sastra lainnya, memiliki padangan dunia yang nyaris sama yaitu dari setiap penceritaan karya sastranya secara garis besar mengangkat 
Fitria Andriani, Didi Yulistio, Agus Trianto

Strukturalisme Genetik dalam Novel Alita @ Heart Karya Dewie Sekar

tema keiklasan yang berkeyakinan semua yang terjadi tidaklah secara tiba-tiba melainkan telah diatur oleh Allah Swt. Tema ini merupakan dasar utama yang akan kita simpulkan setelah membaca karya-karyanya. Dewie Sekar merupakan seseorang yang dilahirkan di kawasan antara dua gunung kembar yaitu Gunung Sindoro dan Gunung Sumbing. Gunung Sindoro- Sumbing berada di Jawah Tengah memiliki mitos yang berkembang di masyarakat yaitu simbol perwujudan sepasang suami istri yang saling setia. Kepercayaan yang berkembang di masyarkaat ini merupakan tempat di mana Dewie Sekar dilahirkan dan tumbuh dewasa. Mitos ini tentu mempengaruhi pandangan dunia dalam diri Dewie Sekar. Hal ini digambarkan pada penceritaan dalam novel, bagaimana Alita yang menjadi tokoh utama memiliki kesetiaan yang tinggi pada pacarnya Erwin yang telah meninggal.

\section{Simpulan dan Saran}

Novel Alita@ Heart karya Dewie Sekar yang diterbitkan pada Tahun 2011 mengusung beberapa alur yaitu alur yang melukiskan kejadian yang nampak sebagai alur yang melukiskan jalannya cerita yang terdiri dari alur buka yang dimulai di awal penceritaan, alur tengah, mulai terjadinya konflik antar tokoh. Alur puncak, antar tokoh mulai melakukan tindakan atas konflik yang ada. Alur tutup, yaitu tokoh-tokoh dalam novel menemukan jalan penyelesaian dari konflik yang ada. Kemudian, kondisi sosial dan budaya masyarakat yang hidup pada masa Novel Alita @ Heart diciptakan dan juga yang tercermin di dalam novel tersebut adalah kondisi masyarakat yang terjebak dalam kehidupan Jakarta yang penuh dengan kesibukan aktivitas kerja, kemacetan, dan percintaan. Latar kehidupan sosial dan budaya pegarang yang mempengaruhi pandangan duniannya terhadap penciptaan novel Alita @ Heart adalah berdasarkan pada prinsip hidup yang Dewie Sekar yakini yaitu tidak ada yang dinamakan "kebetulan" di dunia ini.

Dari hasil penelitian ini diharapkan khususnya bagi peneliti selanjutnya, perlu ada penelitian lanjutan terhadap penelitian ini dengan menggunakan pendekatan atau sudut pandang yang berlainan sehingga aspek-aspek menarik lainnya dapat dimunculkan. Kemudian, bagi pengajar bahasa Indonesia, novel ini bisa dijadikan salah satu materi ajar tentang novel yang bisa digunakan baik di tingkat SMA maupun perguruan tinggi.

\section{Daftar Pustaka}

Andarini, N. (2018). Analisis Kajian Struktural dalam Novel Maryamah Karpov Karya Andrea Hirata. Edukasi Kultura: Jurnal Bahasa, Sastra dan Budaya, 1(2). doi:10.24114/kultura.v1i2.11709

Anggraini, N. (2019). Analisis Strukturalisme Genetik dalam Novel Midah Simanis Bergigi Emas Karya Pramoedya Ananta Toer. Ksatra: Jurnal Kajian Bahasa dan Sastra, 1(2), 27-40. doi:10.52217/ksatra.v1i2.326

Basid, A., \& Aulia, I. N. (2018). Ideologi Feminisme dalam Novel Zeina Karya Nawal El Saadawi Berdasarkan Perspektif Strukturalisme Genetik Lucius Goldmann. Diksi, 25(1). doi:10.21831/diksi.v25i1.14771 
Fitria Andriani, Didi Yulistio, Agus Trianto

Strukturalisme Genetik dalam Novel Alita @ Heart Karya Dewie Sekar

Lestari, S. (2020). Sosok Perempuan Jawa dalam Novel GGA Prespektif Amangkurat I: Tinjauan Strukturalisme Genetik. Suar Betang, 15(1), 95-106. doi:10.26499/surbet.v15i1.153

Noermanzah, N. N. (2017). Plot in a Collection of Short Stories "Sakinah Bersamamu" Works of Asma Nadia with Feminimism Analysis. Humanus, 16(1), 28. doi:10.24036/jh.v16i1.7015

Nurgiyantoro, B. (2010). Teori Pengkajian Fiksi. Yogyakarta: Gajah Mada University Press.

Ratna, N. K. (2008). Teori Metode dan Teknik Penelitian Sastra. Yogyakarta: Pustaka Pelajar.

Saryono. (2009). Pengantar Apresiasi Sastra. Malang: Universitas Negeri Malang.

Sayuti, S. A. (2000). Berkenalan dengan Prosa Fiksi. Yogyakarta: Gama Media.

Semi, M. A. (1993). Anatomi Sastra. Bandung: Angkasa Raya.

Sugianto, I., \& Huda, N. (2017). Strukturalisme Genetik dalam Cerpen Slum Karya Hanif Nashrullah. Fonema, 4(1). doi:10.25139/fonema.v4i1.413

Sulaeman, A., Goziyah, Purawinangun, I.A., Noermanzah. (2020). Social Value in the Novel Hatta: Aku Datang karena Sejarahby Sergius Sutanto as Teaching Materials in Teaching Literature in Schools. International Journal of Scientific and Technology Research, 9(3). 611-612. http://www.ijstr.org/paperreferences.php?ref=|JSTR-0320-32332

Sundari, I. (2015). Analisis Strukturalisme Genetik Novel Perahu Kertas Karya Dewi Lestari. Diksa: Pendidikan Bahasa dan Sastra Indonesia, 1(2), 28-40. doi:10.33369/diksa.v1i2.3177

Syarifuddin, S. (2020). Perwatakan Tokoh Pergerakan Feminisme dalam Novel Ahlâm Al-Nisâ Al-Harem Karya Fatima Mernissi (Sebuah Kajian Strukturalisme Genetik). Jurnal Adabiya, 21(2), 46. doi:10.22373/adabiya.v21i2.6610

Wicaksono, A. (2017). Kearifan pada Lingkungan Hidup dalam Novel-Novel Karya Andrea Hirata (Tinjauan Strukturalisme Genetik). JENTERA: Jurnal Kajian Sastra, 5(1), 7. doi:10.26499/jentera.v5i1.346

Yuhdi, A. (2018). Pandangan Dunia Pengarang untuk Pembangunan Indonesia Baru dalam Novel Layar Terkembang: Kajian Strukturalisme Genetik. Asas: Jurnal Sastra, 7(1). doi:10.24114/ajs.v7i1.9479 